Key Words:

crystallization

nepheline

Retention:

Permanent

\title{
GLASS COMPOSITIONS FOR THE NEPHELINE PHASE III STUDY
}

Co-author: K. M. Fox

Co-author: T. B. Edwards

JUNE 2009

Savannah River National Laboratory

Savannah River Nuclear Solutions

Aiken, SC 29808 


\section{DISCLAIMER}

This work was prepared under an agreement with and funded by the U.S. Government. Neither the U. S. Government or its employees, nor any of its contractors, subcontractors or their employees, makes any express or implied:

1. warranty or assumes any legal liability for the accuracy, completeness, or for the use or results of such use of any information, product, or process disclosed; or

2. representation that such use or results of such use would not infringe privately owned rights; or

3. endorsement or recommendation of any specifically identified commercial product, process, or service.

Any views and opinions of authors expressed in this work do not necessarily state or reflect those of the United States Government, or its contractors, or subcontractors.

Printed in the United States of America

Prepared for

U.S. Department of Energy 
Key Words: crystallization nepheline

Retention:

Permanent

\title{
GLASS COMPOSITIONS FOR THE NEPHELINE PHASE III STUDY
}

\author{
Co-author: K. M. Fox
}

Co-author: T. B. Edwards

JUNE 2009

Savannah River National Laboratory

Savannah River Nuclear Solutions

Savannah River Site

Aiken, SC 29808 


\section{REVIEWS AND APPROVALS}

K. M. Fox, Co-author, Process Technology Programs

Date

T. B. Edwards, Co-author, Statistical Consulting Section

Date

D. K. Peeler, Peer Reviewer, Process Technology Programs

Date

C. C. Herman, Manager, Process Technology Programs

Date

S. L. Marra, Manager,

Date

Environmental \& Chemical Process Technology Research Programs

J. E. Occhipinti, Manager

Date

Waste Solidification Engineering 


\section{TABLE OF CONTENTS}

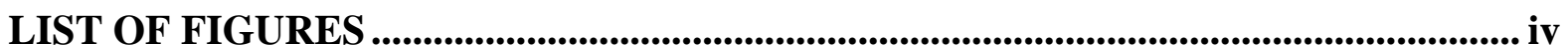

LIST OF TABLES ......................................................................................................................... iv

LIST OF ACRONYMS .................................................................................................................... V

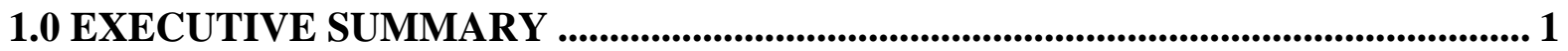

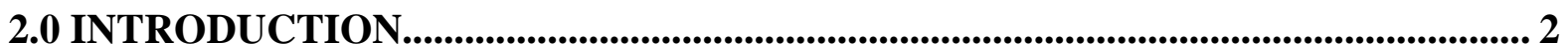

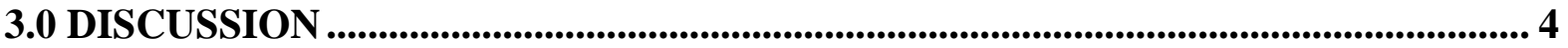

PCCS Model Approach.......................................................................................................... 4

Glass Crystallization Theory Approach ............................................................................... 8

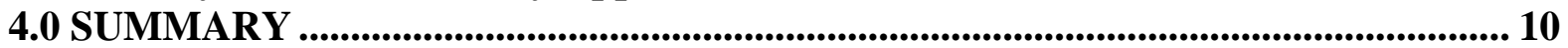

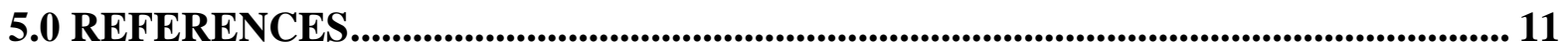




\section{LIST OF FIGURES}

Figure 1. Plot of the nepheline discriminator values for the selected glasses using the current and newly proposed inequalities. ................................................................................... 9

\section{LIST OF TABLES}

Table 3-1. Concentration ranges for the major oxides and Others. 4

Table 3-2. Average composition of the Others category......................................................... 5

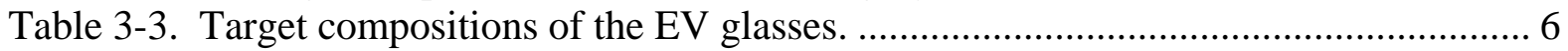

Table 3-4. Target compositions of the SF glasses. ………….............................................. 7 


\section{LIST OF ACRONYMS}

$\begin{array}{ll}\text { ACT } & \text { Activated Complex Theory } \\ \text { DWPF } & \text { Defense Waste Processing Facility } \\ \text { EVs } & \text { Extreme Vertices } \\ \text { LWO } & \text { Liquid Waste Organization } \\ \text { PCCS } & \text { Product Composition Control System }\end{array}$




\subsection{EXECUTIVE SUMMARY}

A series of 29 test glass compositions were selected for Phase III of the nepheline study using a combination of two approaches. The first approach was based on evaluating the glass composition region allowable by all of the Defense Waste Processing Facility (DWPF) Product Composition Control System (PCCS) models with the exception of the current nepheline discriminator. This approach was taken to determine whether there are glass compositions that, while predicted to crystallize nepheline upon slow cooling, would otherwise be acceptable for processing in the DWPF. The second approach was based on quasicrystalline theory of glass structure, which helped predict compositional regions where nepheline should form. A detailed description of this methodology is forthcoming. The selection strategy outlined here will provide an opportunity to determine experimentally whether the glasses that fail the current nepheline discriminator but pass the newly proposed nepheline discriminator are indeed free of nepheline after slow cooling. If this is the case, these data will serve as a significant step toward reducing conservatism in the current nepheline discriminator.

The 29 glass compositions selected for testing address both the PCCS model and quasicrystalline theory approaches in evaluating both a reduction in conservatism for the current nepheline discriminator and possible implementation of the newly proposed discriminator based on glass structural theory. These glasses will be fabricated and characterized in the laboratory, with the results and conclusions described in a technical report. 


\subsection{INTRODUCTION}

Two routes - one based on the relationship of the current nepheline discriminator model to the other Defense Waste Processing Facility (DWPF) Product Composition Control System (PCCS) models ${ }^{1}$ and the other based on theory of crystallization in mineral and glass melts - were considered in selecting glasses for this phase of the nepheline study. The current nepheline discriminator model limits access to certain compositional regions based solely on the concentrations of silica, alumina and soda in the glass. While this model has been shown to be very effective in identifying glasses that are prone to nepheline crystallization upon slow cooling for DWPF-type compositions, ${ }^{2}$ other waste glass compositions have revealed compositional regions that, while predicted to be prone to nepheline crystallization, are in fact free of nepheline upon slow cooling and have acceptable chemical durabilities. ${ }^{3}$

A Phase I study confirmed that some conservatism exists in the current nepheline discriminator. ${ }^{4}$ Several glass compositions, particularly compositions that targeted higher $\mathrm{Al}_{2} \mathrm{O}_{3}$ concentrations, were shown to be very durable while their nepheline discriminator values were well below the current nepheline discriminator limit of 0.62 . Increased concentrations of $\mathrm{B}_{2} \mathrm{O}_{3}$ and $\mathrm{CaO}$ were shown to improve durability responses and suppress the formation of nepheline. These results provided incentive to revise the nepheline discriminator to reduce some of this conservatism and incorporate the influence of $\mathrm{B}_{2} \mathrm{O}_{3}$. The Phase I study suggested that a second phase be undertaken to provide additional data in support of this revision. ${ }^{4}$

Twenty five glass compositions were subsequently selected for a Phase II study on reduction of conservatism in the nepheline discriminator. ${ }^{5}$ The glass compositions were restricted to regions that fell within the validation ranges of the DWPF PCCS models. The glasses were fabricated in the laboratory and characterized for crystallization and chemical durability after both quenching and slow cooling. Nepheline was identified in one of the quenched glasses and several of the CCC glasses. A partitioning algorithm was used to identify trends in crystallization behavior based on glass composition. Generally, for the slowly cooled glasses $\mathrm{MnO}$ influenced the crystallization of spinels and $\mathrm{B}_{2} \mathrm{O}_{3}$ and $\mathrm{SiO}_{2}$ influenced the crystallization of nepheline. Durability responses varied from acceptable to unacceptable depending on the glass composition and type and extent of crystallization that occurred. It was not possible to identify any linear effects of composition on chemical durability performance for this set of study glasses. The results of the Phase II study alone were not sufficient to recommend modification of the current nepheline discriminator. It was recommended that the next series of experiments continue to focus not only on compositional regions where the PCCS models are considered applicable (i.e., the model validation ranges), but also be restricted to compositional regions where acceptable glasses are predicted to be produced but are disallowed by the current nepheline discriminator. ${ }^{5}$

The intent of this Phase III study is to investigate whether there are compositional regions available, particularly glasses with higher aluminum concentrations to support higher waste loadings that are acceptable by all of the PCCS models with the exception of the 
nepheline discriminator. That is, is there unnecessary conservatism present in the current nepheline discriminator model that disallows access to glass compositions that are both acceptable by all of the other PCCS models and in fact free of nepheline crystallization? Two approaches, outlined in the sections below, were taken to select glass compositions for this study.

This work is performed in response to a request ${ }^{6}$ from the Liquid Waste Organization (LWO) and is controlled under a Task Technical and Quality Assurance Plan. ${ }^{7}$ 


\subsection{DISCUSSION}

\section{PCCS MODEL APPROACH}

A statistically driven design of experiments was used to determine the compositional region that is ruled out by the current nepheline discriminator yet otherwise acceptable by the other PCCS models. If a sub-region within this compositional space can be identified where the glasses do not form nepheline, it may be possible to revise the nepheline discriminator to incorporate this region, potentially allowing access to higher waste loadings for the DWPF.

Twelve of the major oxides in a DWPF-type glass composition were considered in developing the compositional region for study. Concentration ranges for these major oxides were chosen using the model applicability and model validation ranges for the PCCS models and recent reduction of constraints studies ${ }^{8}$ as a guide to represent possible compositions that could be processed at the DWPF. These concentration ranges are given in Table 3-1. Note that uranium will not be used in fabricating the study glasses to simplify sample handling. The compositions will be normalized to $100 \mathrm{wt} \%$ without the $\mathrm{U}_{3} \mathrm{O}_{8}$ component. This will not impact the objectives of this task, although follow-on work would likely include uranium before any changes were implemented in PCCS.

Table 3-1. Concentration ranges for the major oxides and Others.

\begin{tabular}{|c|c|c|}
\hline Oxide & $\begin{array}{c}\text { Minimum } \\
\text { (wt \%) }\end{array}$ & $\begin{array}{c}\text { Maximum } \\
\text { (wt \%) }\end{array}$ \\
\hline $\mathrm{Al}_{2} \mathrm{O}_{3}$ & 3.25 & 18.00 \\
\hline $\mathrm{B}_{2} \mathrm{O}_{3}$ & 4.5 & 14.00 \\
\hline $\mathrm{CaO}$ & 0.00 & 4.00 \\
\hline $\mathrm{Cr}_{2} \mathrm{O}_{3}$ & 0 & 0.20 \\
\hline $\mathrm{Fe}_{2} \mathrm{O}_{3}$ & 5.00 & 21.00 \\
\hline $\mathrm{Li}_{2} \mathrm{O}$ & 4.00 & 7.00 \\
\hline $\mathrm{MgO}$ & 0.00 & 1.50 \\
\hline $\mathrm{MnO}$ & 0.30 & 5.50 \\
\hline $\mathrm{Na}_{2} \mathrm{O}$ & 10.00 & 18.00 \\
\hline $\mathrm{NiO} \mathrm{O}$ & 0.00 & 2.50 \\
\hline $\mathrm{SiO}_{2}$ & 30.00 & 55.00 \\
\hline $\mathrm{TiO}_{2}$ & 0.00 & 2.00 \\
\hline $\mathrm{U}_{3} \mathrm{O}_{8}$ & 0.00 & 9.50 \\
\hline $\mathrm{Others}$ & 0.00 & 2.00 \\
\hline
\end{tabular}

Note that an Others category is also included in Table 3-1. This category represents a group of minor oxides typically present in a DWPF-type glass composition. The average concentrations of the oxides included in the Others category are given in Table 3-2. 
Table 3-2. Average composition of the Others category.

\begin{tabular}{|c|c|}
\hline Oxide & $\begin{array}{c}\text { Average concentration } \\
\text { (wt \%) }\end{array}$ \\
\hline $\mathrm{BaO}$ & 4.00 \\
\hline $\mathrm{Ce}_{2} \mathrm{O}_{3}$ & 18.03 \\
\hline $\mathrm{CdO}$ & 14.82 \\
\hline $\mathrm{CuO}$ & 6.41 \\
\hline $\mathrm{La}_{2} \mathrm{O}_{3}$ & 4.89 \\
\hline $\mathrm{PbO}^{2-}$ & 10.82 \\
\hline $\mathrm{SO}_{4}{ }^{2-}$ & 24.04 \\
\hline $\mathrm{ZnO}_{2}$ & 6.73 \\
\hline $\mathrm{ZrO}_{2}$ & 10.26 \\
\hline
\end{tabular}

A statistical analysis software package ${ }^{a}$ was used to identify a region within the bounds defined in Table 3-1 where the compositions fail the current nepheline discriminator but are acceptable by the other DWPF PCCS control models. The software was then used to optimally select 14 compositions from the corner points, or extreme vertices (EVs), of this sub-region. The compositions of the 14 EVs (optimally selected for a linear model of the 13 major oxides plus the Others category) are listed in Table 3-3 after removing the radioactive components and normalizing to $100 \mathrm{wt} \%$. These define the compositions of the first set of glasses to be fabricated and characterized in the laboratory.

Since the EVs represent the extremes of the compositional region where the glasses are acceptable by all of the PCCS models except for the nepheline discriminator, a second strategy was used to select additional glasses within the region of interest. An approach based on a space-filling algorithm was used to identify glass compositions that fall within the extreme vertices to better map the compositional space. Approximately 400 spacefilling compositions were identified. This number was chosen as a compromise between sufficient coverage of the compositional space and reasonable computing times. The compositions resulting from the space-filling approach were then evaluated against the PCCS MAR. These evaluations yielded 15 of the space-filling glasses that passed all of the model constraints except for the nepheline discriminator. These compositions define the second set of glasses to be examined experimentally, and their compositions are listed in Table 3-4 after removing the radioactive components and normalizing to $100 \mathrm{wt} \%$.

\footnotetext{
${ }^{\text {а }} \mathrm{JMP}^{\mathrm{TM}}$, Ver. 6.0.3, SAS Institute Inc., Cary, NC (2006).
} 
Table 3-3. Target compositions of the EV glasses.

\begin{tabular}{|c|c|c|c|c|c|c|c|c|c|c|c|c|c|c|}
\hline Oxide & EV-350 & EV-352 & EV-354 & EV-349 & EV-356 & EV-348 & EV-358 & EV-359 & EV-357 & EV-346 & EV-347 & EV-353 & EV-355 & EV-351 \\
\hline $\mathrm{Al}_{2} \mathrm{O}_{3}$ & 10.53 & 12.69 & 12.86 & 13.38 & 14.51 & 14.38 & 14.65 & 14.20 & 16.08 & 14.70 & 16.18 & 17.02 & 17.19 & 18.00 \\
\hline $\mathrm{B}_{2} \mathrm{O}_{3}$ & 4.51 & 7.22 & 8.82 & 4.62 & 12.11 & 11.23 & 11.51 & 8.66 & 6.64 & 7.43 & 7.07 & 7.86 & 7.87 & 5.30 \\
\hline $\mathrm{BaO}$ & 0.00 & 0.08 & 0.08 & 0.00 & 0.09 & 0.08 & 0.00 & 0.00 & 0.09 & 0.08 & 0.00 & 0.00 & 0.06 & 0.08 \\
\hline $\mathrm{CaO}$ & 4.00 & 0.00 & 4.00 & 0.19 & 0.00 & 0.01 & 1.46 & 3.04 & 4.42 & 0.99 & 0.00 & 0.92 & 0.00 & 4.00 \\
\hline $\mathrm{CdO}$ & 0.00 & 0.30 & 0.30 & 0.00 & 0.32 & 0.31 & 0.00 & 0.00 & 0.33 & 0.30 & 0.00 & 0.00 & 0.21 & 0.30 \\
\hline $\mathrm{Ce}_{2} \mathrm{O}_{3}$ & 0.00 & 0.36 & 0.36 & 0.00 & 0.39 & 0.38 & 0.00 & 0.00 & 0.40 & 0.36 & 0.00 & 0.00 & 0.25 & 0.36 \\
\hline $\mathrm{Cr}_{2} \mathrm{O}_{3}$ & 0.20 & 0.00 & 0.10 & 0.00 & 0.22 & 0.05 & 0.00 & 0.00 & 0.00 & 0.00 & 0.22 & 0.20 & 0.15 & 0.00 \\
\hline $\mathrm{CuO}$ & 0.00 & 0.13 & 0.13 & 0.00 & 0.14 & 0.14 & 0.00 & 0.00 & 0.14 & 0.13 & 0.00 & 0.00 & 0.09 & 0.13 \\
\hline $\mathrm{Fe}_{2} \mathrm{O}_{3}$ & 9.03 & 8.67 & 10.90 & 11.56 & 5.39 & 15.75 & 14.85 & 7.16 & 5.76 & 11.79 & 13.08 & 9.14 & 5.00 & 11.94 \\
\hline $\mathrm{La}_{2} \mathrm{O}_{3}$ & 0.00 & 0.10 & 0.10 & 0.00 & 0.11 & 0.10 & 0.00 & 0.00 & 0.11 & 0.10 & 0.00 & 0.00 & 0.07 & 0.10 \\
\hline $\mathrm{Li}_{2} \mathrm{O}$ & 4.00 & 4.00 & 4.00 & 4.96 & 5.41 & 4.23 & 4.22 & 6.37 & 4.71 & 4.36 & 7.20 & 4.10 & 4.88 & 7.00 \\
\hline $\mathrm{MgO}$ & 1.50 & 0.00 & 0.00 & 0.00 & 1.62 & 0.12 & 0.32 & 0.90 & 0.00 & 1.51 & 0.00 & 0.00 & 0.00 & 0.00 \\
\hline $\mathrm{MnO}$ & 3.50 & 5.50 & 3.45 & 0.31 & 0.32 & 0.69 & 2.66 & 0.69 & 0.33 & 1.99 & 3.98 & 0.64 & 4.38 & 0.30 \\
\hline $\mathrm{Na}_{2} \mathrm{O}$ & 17.34 & 15.56 & 13.69 & 18.48 & 15.27 & 11.24 & 11.32 & 14.04 & 13.19 & 13.26 & 11.01 & 13.53 & 18.00 & 11.73 \\
\hline $\mathrm{NiO}$ & 1.88 & 0.00 & 0.46 & 0.00 & 0.00 & 0.51 & 0.00 & 2.39 & 2.76 & 0.00 & 0.46 & 0.41 & 2.36 & 0.00 \\
\hline $\mathrm{PbO}$ & 0.00 & 0.22 & 0.22 & 0.00 & 0.23 & 0.23 & 0.00 & 0.00 & 0.24 & 0.22 & 0.00 & 0.00 & 0.15 & 0.22 \\
\hline $\mathrm{SO}_{4}{ }^{2-}$ & 0.00 & 0.48 & 0.48 & 0.00 & 0.52 & 0.51 & 0.00 & 0.00 & 0.53 & 0.48 & 0.00 & 0.00 & 0.34 & 0.48 \\
\hline $\mathrm{SiO}_{2}$ & 41.51 & 42.37 & 39.43 & 46.51 & 42.19 & 37.56 & 36.98 & 42.36 & 43.90 & 41.95 & 40.79 & 45.67 & 38.77 & 37.73 \\
\hline $\mathrm{TiO}_{2}$ & 2.00 & 2.00 & 0.28 & 0.00 & 0.80 & 2.12 & 2.03 & 0.18 & 0.00 & 0.00 & 0.00 & 0.52 & 0.00 & 2.00 \\
\hline $\mathrm{ZnO}$ & 0.00 & 0.14 & 0.14 & 0.00 & 0.15 & 0.14 & 0.00 & 0.00 & 0.15 & 0.14 & 0.00 & 0.00 & 0.09 & 0.13 \\
\hline $\mathrm{ZrO}_{2}$ & 0.00 & 0.21 & 0.21 & 0.00 & 0.22 & 0.22 & 0.00 & 0.00 & 0.23 & 0.21 & 0.00 & 0.00 & 0.14 & 0.20 \\
\hline
\end{tabular}


SRNL-STI-2009-00375, REVISION 0

Table 3-4. Target compositions of the SF glasses.

\begin{tabular}{|c|c|c|c|c|c|c|c|c|c|c|c|c|c|c|c|}
\hline Oxide & SF-179 & SF-284 & SF-145 & SF-328 & SF-172 & SF-193 & SF-295 & SF-286 & SF-136 & SF-129 & SF-106 & SF-84 & SF-272 & SF-307 & SF-58 \\
\hline $\mathrm{Al}_{2} \mathrm{O}_{3}$ & 10.71 & 11.68 & 11.58 & 11.93 & 12.30 & 13.21 & 13.63 & 14.36 & 14.15 & 14.68 & 17.13 & 17.96 & 18.31 & 17.75 & 18.01 \\
\hline $\mathrm{B}_{2} \mathrm{O}_{3}$ & 6.35 & 9.84 & 5.43 & 5.53 & 9.12 & 6.30 & 5.28 & 7.86 & 11.82 & 7.37 & 7.32 & 5.89 & 5.11 & 10.31 & 10.38 \\
\hline $\mathrm{BaO}$ & 0.05 & 0.07 & 0.08 & 0.05 & 0.01 & 0.02 & 0.07 & 0.00 & 0.05 & 0.05 & 0.06 & 0.01 & 0.06 & 0.06 & 0.00 \\
\hline $\mathrm{CaO}$ & 0.06 & 4.18 & 3.79 & 3.69 & 3.86 & 0.30 & 3.36 & 1.15 & 3.97 & 4.07 & 3.42 & 1.37 & 2.32 & 0.02 & 3.04 \\
\hline $\mathrm{CdO}$ & 0.17 & 0.25 & 0.29 & 0.18 & 0.03 & 0.06 & 0.25 & 0.01 & 0.17 & 0.19 & 0.22 & 0.02 & 0.22 & 0.24 & 0.00 \\
\hline $\mathrm{Ce}_{2} \mathrm{O}_{3}$ & 0.21 & 0.30 & 0.35 & 0.22 & 0.04 & 0.07 & 0.31 & 0.01 & 0.20 & 0.23 & 0.26 & 0.03 & 0.26 & 0.29 & 0.01 \\
\hline $\mathrm{Cr}_{2} \mathrm{O}_{3}$ & 0.20 & 0.16 & 0.13 & 0.08 & 0.12 & 0.13 & 0.05 & 0.14 & 0.12 & 0.01 & 0.13 & 0.21 & 0.01 & 0.11 & 0.06 \\
\hline $\mathrm{CuO}$ & 0.07 & 0.11 & 0.13 & 0.08 & 0.01 & 0.02 & 0.11 & 0.01 & 0.07 & 0.08 & 0.09 & 0.01 & 0.09 & 0.10 & 0.00 \\
\hline $\mathrm{Fe}_{2} \mathrm{O}_{3}$ & 6.91 & 7.07 & 10.34 & 5.47 & 7.64 & 5.17 & 5.60 & 10.15 & 5.45 & 5.96 & 5.57 & 7.88 & 6.84 & 5.69 & 8.19 \\
\hline $\mathrm{La}_{2} \mathrm{O}_{3}$ & 0.06 & 0.08 & 0.10 & 0.06 & 0.01 & 0.02 & 0.08 & 0.00 & 0.05 & 0.06 & 0.07 & 0.01 & 0.07 & 0.08 & 0.00 \\
\hline $\mathrm{Li}_{2} \mathrm{O}$ & 4.99 & 4.64 & 4.38 & 5.92 & 5.19 & 5.69 & 7.31 & 4.58 & 5.18 & 5.14 & 7.09 & 5.11 & 5.55 & 4.81 & 4.29 \\
\hline $\mathrm{MgO}$ & 0.53 & 0.20 & 0.37 & 1.34 & 0.85 & 0.18 & 0.94 & 0.06 & 0.29 & 1.19 & 0.83 & 0.32 & 1.37 & 0.52 & 0.76 \\
\hline $\mathrm{MnO}$ & 1.42 & 4.74 & 1.50 & 0.44 & 0.93 & 1.48 & 5.59 & 3.51 & 3.73 & 0.47 & 3.26 & 3.79 & 2.12 & 2.05 & 4.69 \\
\hline $\mathrm{Na}_{2} \mathrm{O}$ & 17.71 & 13.35 & 15.25 & 15.34 & 14.01 & 17.76 & 13.05 & 13.51 & 11.09 & 16.78 & 12.20 & 16.98 & 14.65 & 13.79 & 14.48 \\
\hline $\mathrm{NiO}$ & 2.33 & 0.67 & 1.51 & 2.21 & 0.58 & 0.00 & 0.79 & 0.92 & 0.03 & 1.59 & 0.49 & 1.05 & 1.30 & 1.21 & 0.53 \\
\hline $\mathrm{PbO}$ & 0.12 & 0.18 & 0.21 & 0.13 & 0.02 & 0.04 & 0.18 & 0.01 & 0.12 & 0.14 & 0.16 & 0.02 & 0.16 & 0.18 & 0.00 \\
\hline $\mathrm{SO}_{4}^{2-}$ & 0.27 & 0.40 & 0.47 & 0.29 & 0.05 & 0.09 & 0.41 & 0.02 & 0.27 & 0.31 & 0.35 & 0.04 & 0.35 & 0.39 & 0.01 \\
\hline $\mathrm{SiO}_{2}$ & 47.50 & 39.97 & 42.01 & 46.09 & 44.35 & 48.47 & 41.17 & 42.06 & 42.64 & 40.99 & 39.68 & 38.63 & 39.98 & 42.09 & 35.10 \\
\hline $\mathrm{TiO}_{2}$ & 0.14 & 1.83 & 1.75 & 0.75 & 0.84 & 0.94 & 1.50 & 1.62 & 0.40 & 0.46 & 1.41 & 0.64 & 0.96 & 0.05 & 0.44 \\
\hline $\mathrm{ZnO}$ & 0.08 & 0.11 & 0.13 & 0.08 & 0.01 & 0.03 & 0.11 & 0.01 & 0.08 & 0.09 & 0.10 & 0.01 & 0.10 & 0.11 & 0.00 \\
\hline $\mathrm{ZrO}_{2}$ & 0.12 & 0.17 & 0.20 & 0.13 & 0.02 & 0.04 & 0.17 & 0.01 & 0.12 & 0.13 & 0.15 & 0.02 & 0.15 & 0.17 & 0.00 \\
\hline
\end{tabular}




\section{GLASS CRYSTALLIZATION THEORY APPROACH}

In parallel with development of the PCCS model approach (Section 0), an effort to develop an alternative nepheline discriminator has been undertaken based on quasicrystalline theory of glass structure. This effort will be documented in detail in a forthcoming report. ${ }^{2}$ Briefly, Activated Complex Theory (ACT ${ }^{\mathrm{TM}}$ ) was used to relate simple ratios of the cation components of a series of glasses (a database of 136 DWPF-type compositions where crystallization data after slow cooling were available) to the quasicrystalline phases calculated using NORMCALC ${ }^{\mathrm{TM}}{ }^{3}$. In evaluating various combinations of the cation ratios, it was hypothesized that the tendency of a particular glass composition to crystallize nepheline upon slow cooling may be related to the inequality:

$$
\frac{\mathrm{Si}+\mathrm{B}+\mathrm{P}}{\mathrm{Si}+\mathrm{B}+\mathrm{P}+\mathrm{Na}+\mathrm{K}+\mathrm{Al}+\mathrm{Fe}}>0.50
$$

where the atomic symbols indicate molar percentages of that cation. Glass compositions where this ratio is less than 0.50 are predicted to be prone to nepheline crystallization.

This theory was applied to both sets of glass compositions selected using the PCCS models as described earlier. A comparison of the nepheline discriminator values of the selected glasses using both the current nepheline discriminator and the newly proposed nepheline discriminator is provided in Figure 1. The current nepheline discriminator is represented by the blue, horizontal line $(>=0.62)$ and the newly proposed nepheline discriminator is represented by the red, vertical line $(>0.50)$. Four of the selected glasses fall above the current nepheline discriminator on this plot. However, when measurement uncertainty is applied in the PCCS MAR assessment, these compositions fail the current nepheline discriminator.

The selected glasses fall on either side of the newly proposed nepheline discriminator (vertical line in Figure 1). The selection strategy outlined here will provide an opportunity to determine experimentally whether the glasses that fail the current nepheline discriminator but pass the newly proposed nepheline discriminator are indeed free of nepheline after slow cooling. If this is the case, these data will serve as a significant step toward reducing conservatism in predicting nepheline crystallization.

\footnotetext{
${ }^{2}$ Technical report currently in draft by Carol Jantzen at SRNL.

${ }^{3}$ Jantzen and Pareizs, Journal of Nuclear Materials, accepted for publication.
} 
SRNL-STI-2009-00375, REVISION 0

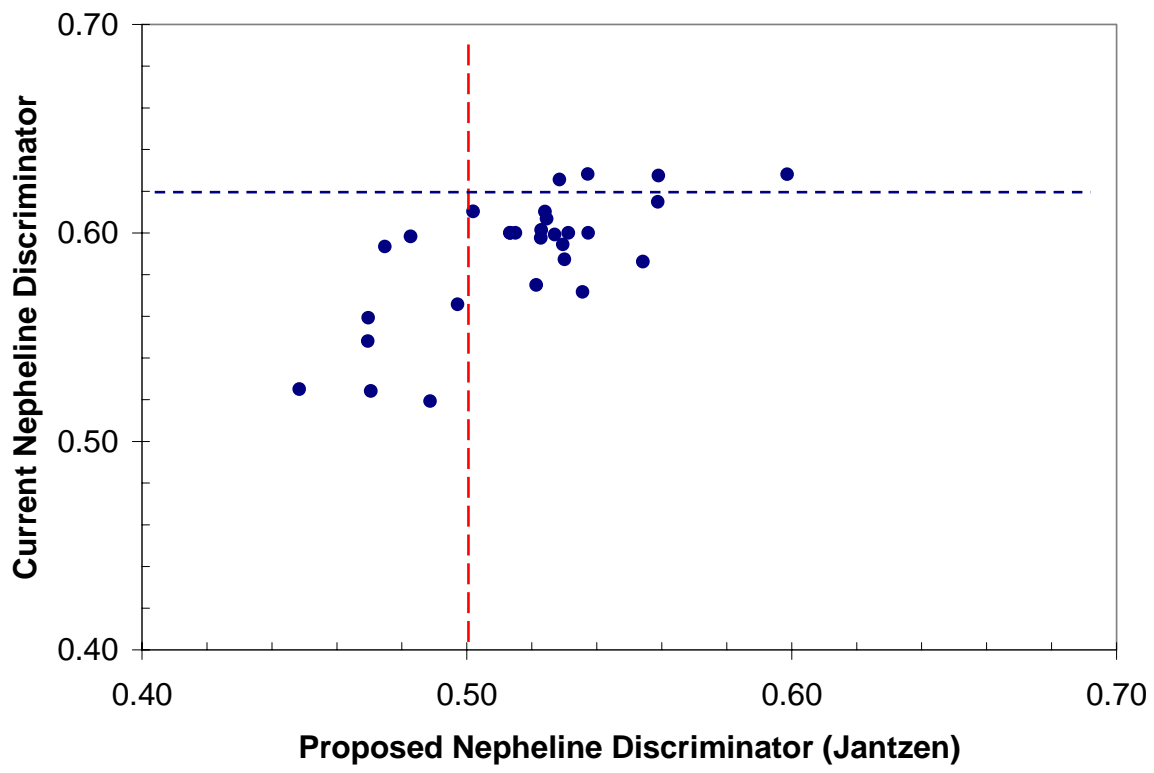

Figure 1. Plot of the nepheline discriminator values for the selected glasses using the current and newly proposed inequalities. 


\subsection{SUMMARY}

A series of 29 test glass compositions were selected for Phase III of the nepheline study using a combination of two approaches. The first approach was based on evaluating the glass composition region allowable by all of the DWPF PCCS models with the exception of the current nepheline discriminator. This approach was taken to determine whether there are glass compositions that, while predicted to crystallize nepheline upon slow cooling, would otherwise be acceptable for processing in the DWPF. The second approach was based on quasicrystalline theory of glass structure. A detailed description of this methodology is forthcoming, but in brief, $\mathrm{ACT}^{\mathrm{TM}}$ was used to relate simple ratios of the cation components of a series of glasses to the quasicrystalline phases calculated using NORMCALC ${ }^{\text {TM }}$. The 29 glass compositions selected for testing address both of these approaches in evaluating both a reduction in conservatism for the current nepheline discriminator and possible implementation of the newly proposed discriminator based on glass structural theory. These glasses will be fabricated and characterized in the laboratory, with the results and conclusions described in a technical report. 


\subsection{REFERENCES}

1. Edwards, T. B., K. G. Brown and R. L. Postles, "SME Acceptability Determination for DWPF Process Control," U.S. Department of Energy Report WSRC-TR-95-00364, Revision 5, Washington Savannah River Company, Aiken, SC (2006).

2. Edwards, T. B., D. K. Peeler and K. M. Fox, "The Nepheline Discriminator: Justification and DWPF PCCS Implementation Details," U.S. Department of Energy Report WSRC-STI2006-00014, Revision 0, Washington Savannah River Company, Aiken, SC (2006).

3. Fox, K. M. and D. K. Peeler, "Demonstration of Very High Aluminum Retention in Simulated HLW Glass," U.S. Department of Energy Report SRNL-PSE-2007-00231, Washington Savannah River Company, Aiken, SC (2007).

4. Fox, K. M., J. D. Newell, T. B. Edwards, D. R. Best, I. A. Reamer and R. J. Workman, "Refinement of the Nepheline Discriminator: Results of a Phase I Study," U.S. Department of Energy Report WSRC-STI-2007-00659, Revision 0, Washington Savannah River Company, Aiken, SC (2008).

5. Fox, K. M. and T. B. Edwards, "Refinement of the Nepheline Discriminator: Results of a Phase II Study," U.S. Department of Energy Report SRNS-STI-2008-00099, Rev. 0, Savannah River National Laboratory, Aiken, SC (2008).

6. Fellinger, T. L., "Technical Task Request: Nepheline Phase III Experimental Work," U.S. Department of Energy Report HLW-DWPF-TTR-2009-0011, Revision 0, Washington Savannah River Company, Aiken, SC (2009).

7. Fox, K. M., "Task Technical and Quality Assurance Plan: Nepheline Phase III Experimental Work," U.S. Department of Energy Report SRNL-RP-2009-00508, Revision 0, Savannah River National Laboratory, Aiken, SC (2009).

8. Raszewski, F. C., T. B. Edwards and D. K. Peeler, "Enhanced DOE High-Level Waste Melter Throughput Studies: SRNL Glass Selection Strategy," U.S. Department of Energy Report WSRC-STI-2007-00652, Revision 0, Washington Savannah River Company, Aiken, SC (2008). 
This page intentionally left blank. 


\section{Distribution:}

C.J. Bannochie, 773-42A

A.L. Billings, 999-W

J.M. Bricker, 704-27S

T.B. Edwards, 999-W

T.L. Fellinger, 704-26S

K.M. Fox, 999-W

C.C. Herman, 999-W

E.W. Holtzscheiter, 704-15S

J.F. Iaukea, 704-30S

C.M. Jantzen, 773-A

P.L. Lee, 773-42A

S.L. Marra, 773-A

D.J. McCabe, 773-42A

R.T. McNew, 704-27S

D.H. Miller, 999-W

J.D. Newell, 999-W

J.E. Occhipinti, 704-S

D.K. Peeler, 999-W

F.C. Raszewski, 999-W

J.W. Ray, 704-S

D.C. Sherburne, 704-S

M.E. Stone, 999-W 